\title{
A Study of the Literary Criticism Style in Xia Zhiqing's The History of Chinese Modern Novels
}

\author{
Shuting Fan ${ }^{1, a}$ \\ ${ }^{1}$ The Hong Kong Polytechnic University Chinese Culture Department, Hong Kong,999077 \\ a1026469089@qq.com
}

Keywords: Xia Zhiqing, The History of Chinese Modern Novels, literary criticism

\begin{abstract}
Xia Zhiqing lived abroad for a long time and published The History of Chinese Modern Novels in 1961. He made a systematic interpretation of Chinese modern novels with a unique perspective of Western criticism. Therefore, this article mainly discusses two aspects: the main structure and the classical discussion of The History of Chinese Modern Novels and the western factors of Xia Zhiqing's literary criticism.
\end{abstract}

\section{Introduction}

The History of Chinese Modern Novels is the first writing commenting on Chinese modern fiction novels, and has made a pioneering historical contribution. Reading this book is greatly helpful for people to understand the development of Chinese modern novels. Therefore, to better study and analyze the characteristics of this work of Xia Zhiqing, especially the literary criticism style, this article mainly discusses some problems from a new angle of view.

\section{The Main Structure and the Classical Discussion of The History of Chinese Modern Novels}

(1) The Main Structure

The History of Chinese Modern Novels mainly deals with modern Chinese literature from the new culture movement in 1917 to the beginning of PRC in 1957, especially the validity of its novel development history. At the same time, Xia Zhiqing also discussed and evaluated other literary forms, such as prose, drama, poetry and so on, which would help the readers to better understand the development of Chinese literature.

Table 1. The structure of The History of Chinese Modern Novels

\begin{tabular}{ll}
\hline Criticism Time & Major Criticism Types \\
\hline $1917-1957$ & Novels, prose, drama and poetry \\
\hline
\end{tabular}

(2) The General Tone

Through his interpretation of Chinese modern novels, Xia Zhiqing defined "People's Literature" and "Obsession with China" as the base tone of interpretation of Chinese modern novels. Specifically, first, in Xia Zhiqing's view, a large number of Chinese scholars and writers influenced by western democracy and science as well as the new culture movement and the May 4th Movement began to study people's literature. On the basis of humanitarianism, they had effectively recorded many social problems and personal issues of the time, resulting in a new form of literature. For example, Xia Zhiqing commented on the situation at that time that, Chinese people in that period were very concerned about the future of Chinese culture. As an important component of the modern Chinese cultural thought in the new era, Chinese traditional thought, like the thinkers of the May 4th period, vowed not to read ancient books, but to proclaim independence to the motherland.

Chinese culture has evolved in one continuous line. To better protect people's livelihood and the peace and prosperity of the country, outstanding performance in the science and literature is needed to develop the characteristics that shine with great splendor. Therefore, our attitude of criticism for these traditional thought, literature and everything is impossible to avoid criticism. Zhou Zuoren's 
People's Literature represented the spirit of May 4th period. Although its tone was fierce, but in which the view of Western literature and pure literature was adopted in the study of the Chinese classical literature, presenting an idea that we need to draw lessons from people's literature.

Second, the spirit of "Obsession with China" has made a profound influence on Chinese modern literature. For example, Xia Zhiqing believes that many writers in the West pay great attention to the description of people's emptiness, attack modern society and feel despair of modern literature. The Chinese writers at that time were also influenced by this trend of thought, paying attention to the analysis of the realistic social problems. For example: on the basis of inheriting the irony device of Liu E and Li Ruzhen in the late Qing Dynasty, some writers paid full attention on the problem of corruption at all levels in China at that time, and showed it in a bare manner in their literary works. In Xia Zhiqing's view, many writers, through depicting people's sufferings and criticizing social ills, fully displayed the conscience of Chinese literati at that time.

Table 2. The History of Chinese Modern Novels' comment on the tone of Chinese modern literature before 1950s

\begin{tabular}{lll}
\hline \multicolumn{2}{c}{ Main Characteristics } & \multicolumn{1}{c}{ Thinking } \\
\hline $\begin{array}{l}\text { People's Literature, Obsession with } \\
\text { China }\end{array}$ & $\begin{array}{l}\text { Concerned about the future of Chinese } \\
\text { culture, the description of the sufferings of } \\
\text { the people, and the profound criticism of } \\
\text { social ills }\end{array}$ \\
\hline
\end{tabular}

In 1950s, China's modern literary criticism at that time maintained a good view of itself, and it was able to publish its own views on some issues. It had admirable features. Litterateurs and writers of this age were the supervisors of social civilization, spirit and times, and had made effective comments and descriptions of human nature, which constantly arouse people to think and argue.

Table 3. The History of Chinese Modern Novels' comment on the tone of Chinese modern literature after 1950s

\begin{tabular}{ll}
\hline Main Characteristics & Thinking \\
\hline $\begin{array}{c}\text { noteworthy conduct and } \\
\text { independent character }\end{array}$ & $\begin{array}{c}\text { To supervise social civilization and the } \\
\text { times, and to make effective comments } \\
\text { and descriptions of human nature }\end{array}$ \\
\hline
\end{tabular}

(3) Comments and Influences on Some Writers

While commenting on Chinese contemporary literature, Xia Zhiqing was deeply influenced by Levis, the western Cambridge literary critic. He paid great attention to the effective characterization and analysis of a writer through his works and rationally praised and criticized human nature to constantly enhance people's aesthetic and moral quality, which is conducive to people's rich and sensitive emotional understanding, and the pursuit of beauty in the life. Therefore, Xia Zhiqing disagreed with the best-writers ranking list of "Lu Xun, Guo Moruo, Mao Dun, Ba Jin, Lao She, Cao $\mathrm{Yu}$ " in mainland China, instead, he believed that Eileen Chang, Qian Zhongshu, Zhang Tianyi, Shen Congwen's name should be listed as the most important writers. At that time, many writers and historians in the mainland China had deliberately chosen to silence or avoid the question of the rank of modern Chinese literature.

But Xia Zhiqing, with a critical spirit and language style, read enormous of literary works of that time on the basis of his own principle of literary criticism and aesthetic characteristics, and placed many writers on the position of equal significance with Lu Xun and Mao Dun. For example, Xia Zhiqing believed that the religious view in Shen Congwen's works well reflected the idyllic atmosphere of Shen's literature. And Zhang Tianyi's works had revealed the human psychology of evil, bigotry and grumpiness with comic satire and exaggeration. In Xia Zhiqing's eyes, Eileen Chang is one of the most tragic dreamers. She used beautiful words for characterization, and had in-depth writing techniques that described not only the immediate things. Qian Zhongshu, in Xia Zhiqing's idea, is the most humorous writer and scholar. Fortress Besieged fully demonstrated his talent, in which the quality and wisdom of all mortal beings in Chinese society were portrayed with deep details [1]. 
Table 4. The History of Chinese Modern Novels' comment on writers

\begin{tabular}{|c|c|c|c|}
\hline Sheng Congwen & Zhang Tianyi & Eileen Chang & Qian Zhongshu \\
\hline Religious view & revealed & Profound & Fortress \\
\hline $\begin{array}{l}\text { reflects the idyllic } \\
\text { atmosphere } \\
\text { literature }\end{array}$ & $\begin{array}{l}\text { human psychology } \\
\text { of evil, bigotry and } \\
\text { grumpiness with } \\
\text { comic satire and } \\
\text { exaggeration }\end{array}$ & $\begin{array}{lr}\text { characterization of } \\
\text { characters } & \text { and } \\
\text { terrific } & \text { writing } \\
\text { techniques } & \end{array}$ & $\begin{array}{l}\text { Besieged depicts } \\
\text { the quality and } \\
\text { wisdom of all the } \\
\text { Chinese society at } \\
\text { that time }\end{array}$ \\
\hline
\end{tabular}

\section{The western factors of Xia Zhiqing's literary criticism}

Xia Zhiqing's literary criticism is deeply influenced by the new criticism theory of the United States and Britain, and at the same time maintains his own style. He pays great attention to the excavation of literary content and reveals its unique aesthetic features. This has a lot to do with Xia Zhiqing's study at Yale University in the middle and late 1940s. He was deeply influenced by the atmosphere of the new criticism literature at that time, and also held the idea of some new literary criticism. Through the research on the history of the novel, Xia Zhiqing made a deep study on the relationship between literature review and national issues. He puts more emphasis on human life and advocates literature education skills, thinking that literature needs to convey the truth in sincerity [2].

Table 5. Xia Zhiqing's westernized literary criticism

\begin{tabular}{cl}
\hline Environment & Literature Criticism Style \\
\hline $\begin{array}{l}\text { Upholding the concept of new literary } \\
\text { criticism }\end{array}$ & $\begin{array}{l}\text { Literature needs to pay attention to the } \\
\text { perception of human life, to have } \\
\text { enlightenment function, to be honest and } \\
\text { convey truth }\end{array}$ \\
\hline
\end{tabular}

\section{Conclusion}

Overseas Sinologist Xia Zhiqing's The History of Chinese Modern Novels has a very broad perspective. In the book he combined the western concept of literary criticism with the traditional Confucian culture in China and conducted a systematic review of Chinese modern fiction, drama, prose and other works from 1957 to 1917, which is conducive to the interpretation and thinking of many literary works in modern China based on criticism and the exploration of the true depth of human nature and psychology in literature criticism, and has a certain reference value for the future development of literature China.

\section{References}

[1] Li X. Nora and her sistersLu Xun' s reflections on the role of women in Chinese society with particular reference to Elfriede Jelinek' s What happened after nora left her husband or pillars of society (1979)[J]. Neohelicon, 2008, 35(2):217-235.

[2] Li X. Nora and her sisters[J]. Neohelicon, 2008, 35(2):217-235. 